\title{
Modulatory effects of naringin on hepatic key enzymes of carbohydrate metabolism in high-fat diet/low-dose streptozotocin-induced diabetes in rats
}

\author{
Leelavinothan Pari and Ramasamy Chandramohan \\ Department of Biochemistry and Biotechnology, Faculty of Science, Annamalai University, Annamalai Nagar-608002, Tamil \\ Nadu, India
}

\begin{abstract}
We evaluated the modulatory effects of naringin on altered hepatic key enzymes of carbohydrate metabolism in high-fat diet/low-dose streptozotocin-induced diabetic rats. Oral treatment of naringin at a doses of 20,40 and $80 \mathrm{mg} / \mathrm{kg}$ body weight (b.w.) to diabetic rats for 30 days resulted in a significant reduction in the levels of plasma glucose, blood glycosylated hemoglobin and increase in the levels of plasma insulin and blood hemoglobin. The altered activities of the hepatic key enzymes of carbohydrate metabolism such as hexokinase, glucose-6-phosphatase, fructose-1,6-bisphosphatase, glucose-6-phosphate dehydrogenase, glycogen synthase, glycogen phosphorylase and glycogen content of diabetic rats were significantly reverted to near normal levels by the treatment of naringin in a dose-dependent manner. Naringin at a dose of $80 \mathrm{mg} / \mathrm{kg}$ b.w. showed the highest significant effect than the other two doses (20 and $40 \mathrm{mg} / \mathrm{kg}$ b.w.). Further, immunohistochemical observation of pancreas revealed that naringin-treated diabetic rats showed the increased number of insulin immunoreactive $\beta$-cells, which confirmed the biochemical findings. These findings revealed that naringin has potential antihyperglycemic activity in high-fat diet/low-dose streptozotocin-induced diabetic rats.
\end{abstract}

Key words: Carbohydrate metabolism - Glucose — High-fat diet — Insulin — Naringin — Streptozotocin

\section{Introduction}

Diabetes mellitus (DM) is one of the most severe and incurable metabolic disease that occurs when the pancreas does not produce enough insulin or alternatively, when the body cannot effectively use the insulin it produces (American Diabetes Association-2011). The world prevalence of DM is currently about 415 million and predicted to reach 642 million by the end of 2040, according to the International Diabetes Federation report (2015) (https:// www.diabetesvic.org.au/images/2015 news/Exec Summary Diabetes Atlas 7.pdf). DM is classified into type 1 and type 2 DM (T2DM) while over $90-95 \%$ of patients are suffering from T2DM (Liu et al. 2013). T2DM is charac-

Correspondence to: Pari Leelavinothan, Department of Biochemistry and Biotechnology, Faculty of Science, Annamalai University, Annamalainagar - 608002, Tamil Nadu, India

E-mail: jayampari@gmail.com terized mainly by insulin resistance and a $\beta$-cell secretory deficiency (Salas-Salvado et al. 2011) with derangement in carbohydrate, protein and lipid metabolism resulting in sustained hyperglycemia.

Liver is an insulin-sensitive tissue and plays a major role in maintaining glucose homeostasis by coordinated regulation of several metabolic pathways including gluconeogenesis and glycolysis (Sundaram et al. 2013). McAnuff et al. (2015) have reported that deterioration of insulin control exacerbates metabolic disturbances by diminishing of the activities of enzymes in the glycolytic and pentose phosphate pathways, while increasing the activities of gluconeogenic and glycogenolytic pathways. These modifications impair peripheral glucose utilization and increase hepatic glucose production (Chandramohan et al. 2015). Since, the regulation of carbohydrate metabolism is the major therapeutic approaches to control the DM and its complications.

Currently available medicines, including insulin and other oral hypoglycemic agents such as biguanide, thiazolidinedi- 
one, sulfonylurea and $\alpha$-glycosidase inhibitors, are used for the treatment of DM. Conversely, these medicines frequently leads to deleterious side effects, such as hypoglycemia, drugresistance, dropsy and weight gain (Prabhakar et al. 2013). For this reason, the detection of novel pharmacological approaches to efficiently prevent, treat and cure this disease without any deleterious side effect is of major consequence. Recently, diabetic healthcare professions had a significant importance in considering complementary and alternative approaches, involving by identifying natural insulin-sensitive and insulin-secretary substance from functional foods and their bioactive compounds to replace synthetic ones (Mirmiran et al. 2014).

Naringin (4',5,7-trihydroxyflavanone 7-rhamnoglucoside) is a major and active flavanone glycoside that is ubiquitous in citrus herbs and grape fruit. Grapes and citrus fruits are common in the diet. The flavonoids in these fruits are known to exert a wide range of benefits and are also experimentally valid to have no side effects (Tapas 2008). Orally administered naringin is metabolized to naringenin (4',5,7-trihydroxyflavanone), which crosses the blood-brain barrier (Zbarsky 2005). It possesses a wide range of biological and pharmacological activities including anti-inflammatory, anti-oxidant, antihyperlipedemic and antihyperglycemic activities (Jeon et al. 2001; Golechha et al. 2011; Chanet et al. 2012; Mahmoud et al. 2012). Despite of these pharmacotherapeutic properties of naringin, its beneficial effects against T2DM using a high-fat diet (HFD) combined with a low-dose of streptozotocin (STZ)-induced diabetic rats model have not been explored. The HFD followed by treatment with low dose of STZ is contemplated to be an innovative animal model, because it could be closely linked to the clinical circumstance in humans and the stages and transitions in the sequence of T2DM (Skovsø 2014). Hence, this study was carried out to examine the role of naringin on the level of plasma glucose, insulin, hemoglobin, glycosylated hemoglobin and some key enzymes of carbohydrate metabolism in a HFD combined with a low-dose of STZinduced diabetic rats.

\section{Materials and Methods}

\section{Chemicals}

Naringin and STZ were purchased from Sigma-Aldrich (St. Louis, MO, USA). Insulin primary antibody was purchased from Santa-Cruz Biotechnology, Inc. (USA). Rabbit anti-mouse secondary antibody was purchased from Genei (Bangalore, India). All other chemicals and solvents used in this study were of analytical grade and purchased from $\mathrm{Hi}$ Media and SD-Fine Chemicals (Mumbai, India).

\section{Experimental animals}

Male albino Wistar rats, weighing about 180-220 g were procured from Central Animal House, Department of Experimental Medicine, Rajah Muthiah Medical College and Hospital, Annamalai University. They were housed in clean, sterile, polypropylene cages at an ambient temperature of $25 \pm 2{ }^{\circ} \mathrm{C}$ and relative humidity of $45-55 \%$ with $12 \mathrm{~h}$ light/dark cycles (light on at 8:00 and light off at 20:00). They had free access to standard rodent pelleted diet (Hindustan Lever Ltd., Bangalore, India) and water ad libitum, prior to the dietary manipulation. The experimental protocol was approved by the Institutional Animal Ethical Committee, Annamalai University (Reg No. 1099, 2014).

\section{Experimental design}

The rats were randomly divided into 2 groups: group 1 ( $n=$ 12) was fed with normal pellet diet (NPD) (9\% fat, $20 \%$ protein, $53 \%$ starch, $5 \%$ fiber) and group $2(n=24)$ fed with HFD (25\% fat, $15 \%$ protein, $51 \%$ starch and $5 \%$ fiber) (Jian et al. 1998) for one month. After one month on their respective diets, rats from group 2 rats were intraperitoneally injected with STZ dissolved in $0.1 \mathrm{M}$ citrate buffer ( $\mathrm{pH}$ 4.5) at a dose of $25 \mathrm{mg} / \mathrm{kg}$ body weight (b.w.). Rats with fasting plasma glucose over $250 \mathrm{mg} / \mathrm{dl}, 3$ days after STZ injection were considered diabetic and used for the study. The diabetic rats were fed on the HFD until the end of the experiment. Normal and diabetic rats were divided into six groups as follows: NC, normal control rats $(n=6) ; \mathrm{N}+80 \mathrm{~N}$, normal rats treated with naringin ( $80 \mathrm{mg} / \mathrm{kg}$ b.w.; $n=6) ; \mathrm{D}, \mathrm{HFD}$ with STZ-induced diabetic control rats $(n=6) ; \mathrm{D}+20 \mathrm{~N}$, HFD with STZ-induced diabetic rats treated with naringin (20 mg/kg b.w.; $n=6$ ); D+40N, HFD with STZ-induced diabetic rats treated with naringin $(40 \mathrm{mg} / \mathrm{kg}$ b.w.; $n=6)$; $\mathrm{D}+80 \mathrm{~N}, \mathrm{HFD}$ with STZ-induced diabetic rats treated with naringin $(80 \mathrm{mg} / \mathrm{kg}$ b.w.; $n=6)$. Naringin was dissolved in water and administered orally by intragastric intubation, daily for a period of 30 days.

At the end of the experimental period, all the rats were fasted overnight and sacrificed by cervical decapitation. Blood samples were collected in tubes containing potassium oxalate and sodium fluoride (3:1) mixture for the estimation of plasma glucose and insulin. The liver tissue was immediately dissected, washed in ice-cold saline to remove the blood. Also, pancreas was collected in $10 \%$ formalin solution and immediately processed for histological study by the paraffin technique. A portion of the liver tissues were minced and homogenized $(10 \%, \mathrm{w} / \mathrm{v})$ with $0.1 \mathrm{M}$ Tris-HCl buffer ( $\mathrm{pH} 7.4)$ and centrifuged (3000 $\times g$ for $10 \mathrm{~min}$ ). The resulting supernatant was used as an enzyme source for the estimation of various parameters. 
Another portion of wet liver tissue was used for the estimation of glycogen content.

\section{Biochemical estimations}

Plasma glucose was estimated using a commercial kit (Sigma Diagnostics Pvt. Ltd., Baroda, India) by the method of Trinder (1969). Plasma insulin was assayed by ELISA kit (Boeheringer-Manneheim Kit, Manneheim, Germany). Total hemoglobin $(\mathrm{Hb})$ and glycosylated hemoglobin (HbA1c) were estimated in the whole blood by diagnostic kits (Agappe Diagnostic Pvt. Ltd., India).

\section{Oral glucose tolerance test}

Oral glucose tolerance test (OGTT) was performed according to the method of Du Vigneaud and Karr (1925). After overnight fasting on $31^{\text {st }}$ day, ' 0 ' minute blood sample $(0.2 \mathrm{ml})$ was taken from control and experimental rats. Without delay, a glucose solution ( $2 \mathrm{~g} / \mathrm{kg}$ b.w.) was administered by oral gavage. Blood samples were taken at 30, 60, 90 and 120 min after glucose administration.

\section{Assay of carbohydrate metabolic enzymes}

Hepatic glucokinase activity was assayed by the method of Brandstrup et al. (1957). The reaction mixture in a total volume of $5.3 \mathrm{ml}$ contained: $1 \mathrm{ml}$ of glucose $(5 \mathrm{mM})$ solution, $0.5 \mathrm{ml}$ of ATP (72 mM) solution, $0.1 \mathrm{ml}$ of $\mathrm{MgCl}_{2}$ (50 $\mathrm{mM}$ ) solution, $0.4 \mathrm{ml}$ of potassium dihydrogen phosphate $(125 \mathrm{mM}), 0.4 \mathrm{ml}$ of $\mathrm{KCl}(100 \mathrm{mM}), 0.4 \mathrm{ml}$ of $\mathrm{NaF}$ $(0.5 \mathrm{M})$ and $2.5 \mathrm{ml}$ of Tris- $\mathrm{HCl}$ buffer $(10 \mathrm{mM}, \mathrm{pH} 8.0)$. The mixture was pre-incubated at $37^{\circ} \mathrm{C}$ for $5 \mathrm{~min}$. The reaction was initiated by the addition of $2 \mathrm{ml}$ of tissue homogenate. $1 \mathrm{ml}$ of the reaction mixture was immediately transferred to the tubes containing $1 \mathrm{ml}$ of $10 \%$ trichloroacetic acid (TCA) that was considered as zero time. A second aliquot was removed and deproteinised after $30 \mathrm{~min}$ incubation at $37^{\circ} \mathrm{C}$. The protein precipitate was removed by centrifugation and the residual glucose in the supernatant of tissue homogenate was estimated by the method of Trinder (1969).

Glucose-6-phosphate dehydrogenase in the liver was assayed by the method of Ells and Kirkman (1961). The incubation mixture contained $1 \mathrm{ml}$ of Tris- $\mathrm{HCl}$ buffer $(50 \mathrm{mM}$, $\mathrm{pH} 7.5), 0.1 \mathrm{ml}$ of $\mathrm{MgCl}_{2}(0.1 \mathrm{M}), 0.1 \mathrm{ml}$ of $\operatorname{NADP}(0.1 \mathrm{M})$, $0.5 \mathrm{ml}$ of phenazine methosulphate, $0.4 \mathrm{ml}$ of dye solution and required amount of the enzyme extract. The mixture was allowed to stand for $10 \mathrm{~min}$ at room temperature to permit the oxidation of endogenous materials. The reaction was initiated by the addition of $0.5 \mathrm{ml}$ of glucose-6-phosphate. Absorbance of the sample was read at $640 \mathrm{~nm}$ against the blank at 1 -min interval for 3-5 min. The enzyme activity was expressed in units by multiplying the change in OD/ min by the factor $6 / 17.6$, the molar extinction co-efficient of the reduced co-enzyme.

Hepatic glucose-6-phosphatase activity was assayed by the method of Koide and Oda (1959). Incubation mixture contained $0.7 \mathrm{ml}$ of citrate buffer $(0.1 \mathrm{M}, \mathrm{pH} 6.5), 0.3 \mathrm{ml}$ of substrate $(10 \mathrm{mM})$ and $0.3 \mathrm{ml}$ of tissue homogenate. The reaction mixture was incubated at $37^{\circ} \mathrm{C}$ for $1 \mathrm{~h}$. Addition of $1 \mathrm{ml}$ of $10 \%$ TCA to the reaction tubes terminated the reaction of the enzyme. The suspension was centrifuged and the phosphorus content of the supernatant of tissue homogenates were estimated by the method of Fiske and Subbarow (1925). The supernatant was adjusted to a known volume. To this, $1 \mathrm{ml}$ of ammonium molybdate was added followed by $0.4 \mathrm{ml}$ of amino naphthol sulphonic acid (ANSA). After $20 \mathrm{~min}$, the absorbance was read at $680 \mathrm{~nm}$.

Fructose-1,6-bisphosphatase activity in the liver was measured by the method of Gancedo and Gancedo (1971). The assay mixture in a final volume of $2 \mathrm{ml}$ contained $1.2 \mathrm{ml}$ of Tris- $\mathrm{HCl}$ buffer $(0.1 \mathrm{M}, \mathrm{pH} 7.0), 0.1 \mathrm{ml}$ of substrate (50 mM), $0.25 \mathrm{ml}$ of $\mathrm{MgCl}_{2}(0.1 \mathrm{M}), 0.1 \mathrm{ml}$ of potassium chloride solution $(0.1 \mathrm{M}), 0.25 \mathrm{ml}$ of ethylene diamine tetra acetic acid (EDTA) $(1 \mathrm{mM})$ solution and $0.1 \mathrm{ml}$ of enzyme source. The incubation was carried out at $37^{\circ} \mathrm{C}$ for $5 \mathrm{~min}$. The reaction was terminated by the addition of $10 \%$ TCA. The suspension was centrifuged and the supernatant was used for the estimation of phosphorus by the method of Fiske and Subbarow (1925) as described previously. The estimation of protein was carried out by the method of Lowry et al. (1951).

\section{Estimation/assay of glycogen and glycogen metabolic enzymes}

The hepatic glycogen was extracted and estimated by the method of Morales et al. (1973). $0.5 \mathrm{ml}$ of tissue homogenate was mixed with $0.5 \mathrm{ml}$ of $10 \%$ TCA and centrifuged for $10 \mathrm{~min}$. The precipitate was dissolved in $1 \mathrm{ml}$ of $0.1 \mathrm{~N}$ sodium hydroxide. From this, an aliquot was taken, and $4.5 \mathrm{ml}$ of alkaline copper reagent was added and allowed to stand at room temperature for $10 \mathrm{~min}$. $0.5 \mathrm{ml}$ of Folin's phenol reagent was added and the blue color developed was read after $20 \mathrm{~min}$ at $640 \mathrm{~nm}$.

Glycogen synthase activity in the liver was measured according to the procedure of Golden et al. (1977). Samples of liver $(0.2-0.4 \mathrm{~g})$ were homogenized in $2.0 \mathrm{ml}$ of Tris- $\mathrm{HCl}$ buffer, $\mathrm{pH}$ 7.8, containing $10 \mathrm{mM}$ EDTA, $5 \mathrm{mM}$ dithiothreitol, $50 \mathrm{mM} \mathrm{NaF}$, and $2.5 \mathrm{~g} / \mathrm{l}$ rabbit liver glycogen type III (Sigma, Poole, UK). The homogenate was centrifuged at $10,000 \times g$ for $30 \mathrm{~s}$ in an MSE microcentrifuge and the supernatant was used for glycogen synthase assay by measuring the incorporation of uridine diphosphate (UDP)-U-glucose into glycogen at $30^{\circ} \mathrm{C}$. The final concentration of UDP-glucose in the assay was $6.7 \mathrm{mM}$. Total 
glycogen synthase activity was measured in the presence of $10 \mathrm{mM}$ glucose-6-phosphate.

Glycogen phosphorylase was estimated by the method of Shull et al. (1956). The liver tissue was homogenized in $0.1 \mathrm{M}$ $\mathrm{NaF}$ at $0^{\circ} \mathrm{C}$ to get a $15 \%$ homogenate. Suitable amounts of liver homogenates were pipetted into graduated centrifuge tubes containing $0.7 \mathrm{ml}$ of $\mathrm{NaF}, 0.2 \mathrm{ml}$ of glucose 1 -phosphate, $0.6 \mathrm{ml}$ of $0.1 \mathrm{M}$ citrate buffer ( $\mathrm{pH} 5.8$ ) and $0.1 \mathrm{ml}$ of glycogen. The volume was made up to $2.0 \mathrm{ml}$ with distilled water. The reaction mixture was incubated for $30 \mathrm{~min}$ at $30^{\circ} \mathrm{C}$ and then the reaction was stopped by the addition of $1.0 \mathrm{ml}$ of ice cold $10 \%$ TCA. The volume was made up to $10 \mathrm{ml}$ and the tubes were then kept in an ice bath for $20 \mathrm{~min}$. Then, they were centrifuged and the solution was filtered through Whatman paper No. 42. The filtrate was then taken for the
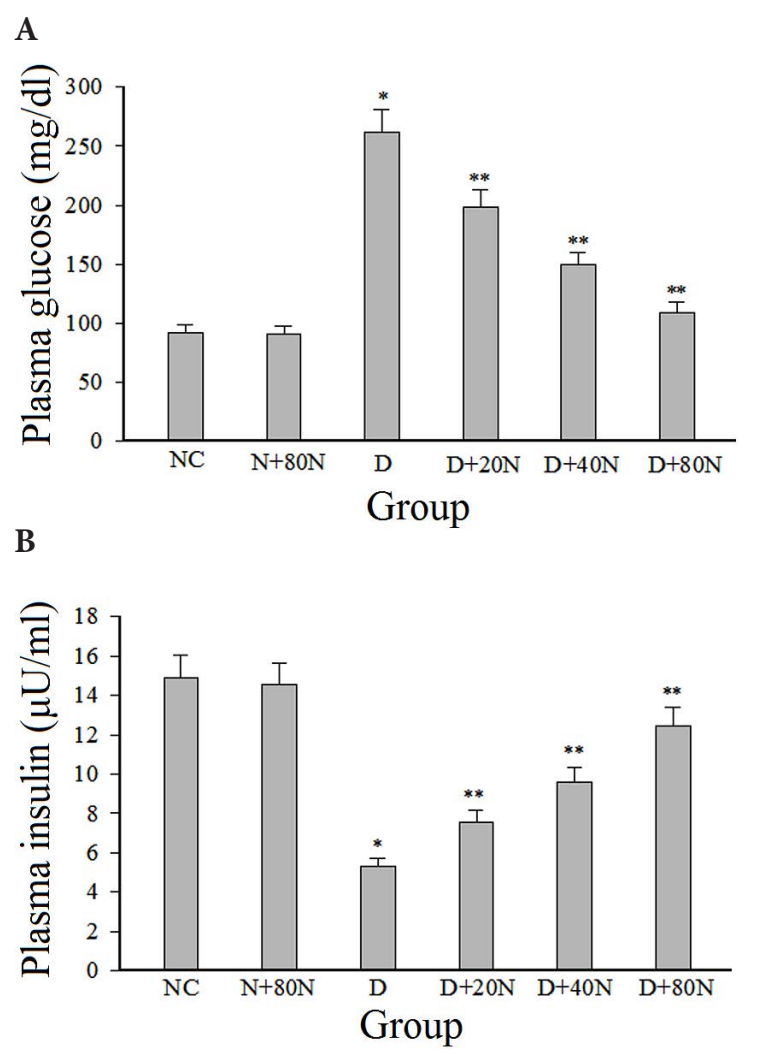

Figure 1. Effect of naringin on plasma glucose (A) and insulin (B) levels. Groups: $\mathrm{NC}$, normal control rats; $\mathrm{N}+80 \mathrm{~N}$, normal rats treated with naringin ( $80 \mathrm{mg} / \mathrm{kg}$ b.w.); D, HFD with STZ-induced diabetic control rats; D+20N, HFD with STZ-induced diabetic rats treated with naringin $(20 \mathrm{mg} / \mathrm{kg}$ b.w.); D+40N, HFD with STZ-induced diabetic rats treated with naringin $(40 \mathrm{mg} / \mathrm{kg}$ b.w.); D+80N, HFD with STZ-induced diabetic rats treated with naringin $(80 \mathrm{mg} /$ $\mathrm{kg}$ b.w.). Each column is mean \pm S.D. for six rats in each group. ${ }^{*} p<0.05$ as compared to normal control; ${ }^{* *} p<0.05$ as compared to HFD+STZ-induced diabetic control. STZ, streptozotocin; HFD, high-fat diet. estimation of inorganic phosphorus by the method of Fiske and Subbarow (1925).

\section{Immunohistochemical study}

The $5 \mu \mathrm{m}$ thick paraffin-embedded pancreatic sections were deparaffinized by heating at $60^{\circ} \mathrm{C}$ for $60 \mathrm{~min}$, followed by three washes with xylene. After gradual hydration through graded alcohol, the slides were incubated in $10 \mathrm{mM}$ sodium citrate buffer ( $\mathrm{pH} 6.0$ ) at 2 cycles for $5 \mathrm{~min}$ in a microwave oven for antigen retrieval. The sections were allowed to cool for $20 \mathrm{~min}$ and then rinsed with phosphate-buffered saline (PBS). The sections were treated with peroxidase block for $10 \mathrm{~min}$ to inhibit endogenous peroxidase activity. Non-specific antibody binding was reduced by incubating the sections with Universal Power Block for $10 \mathrm{~min}$. The sections were then treated for $40 \mathrm{~min}$ at room temperature with $2 \%$ bovine serum albumin and incubated with insulin mouse polyclonal antibody (dilution 1:500) at room temperature for $3 \mathrm{~h}$. The slides were washed with PBS and then incubated with biotin-labelled polymer HRP secondary antibody followed by streptavidin-biotin-peroxidase. The immunoprecipitate was visualized by treating with 3,3'-diaminobenzidine and counterstained with Mayer hematoxylin.

\section{Statistical analysis}

Data presented as means \pm standard deviation (S.D.) and subjected to statistical significance were evaluated by one-way analysis of variance (ANOVA) using Statistical Package for the Social Sciences (SPSS) software package version 17.0 (SPSS, Cary, NC, USA) and the individual comparisons were obtained by Duncan's Multiple Range Test (DMRT). Values are considered statistically significant when $p<0.05$.

\section{Results}

Dose-dependent effect of naringin on the levels of plasma glucose, insulin and glucose tolerance

The levels of plasma glucose were significantly $(p<0.05)$ increased whereas plasma insulin levels were significantly $(p<0.05)$ decreased in HFD and STZ-induced diabetic control rats when compared to normal control rats. Treatment with naringin daily for a period of 30 days to HFD and STZ-induced diabetic rats significantly $(p<0.05)$ decreased the levels of plasma glucose and significantly $(p<0.05)$ increased the levels of plasma insulin in a dosedependent manner when compared with diabetic control groups (Figure 1). 
Oral glucose tolerance test showed the blood glucose reached the fasting levels at $120 \mathrm{~min}$, after an oral dose of glucose in normal control rats. However, in HFD and STZ-induced diabetic control rats, the blood glucose levels remained elevated even after $120 \mathrm{~min}$. Treatment with naringin showed a significant decrease in blood glucose levels in a dose-dependent manner when compared with diabetic control groups (Figure 2). Naringin at dose of $80 \mathrm{mg} / \mathrm{kg}$ b.w. showed the highest significant $(p<0.05)$ effect when compared to other two doses (20 and $40 \mathrm{mg} / \mathrm{kg}$ b.w.). Based on these data, the effective dose of naringin was fixed as $80 \mathrm{mg} / \mathrm{kg}$ b.w. and used for further studies.

\section{Effect of naringin on the levels of blood $\mathrm{Hb}$ and $\mathrm{HbAlc}$}

HFD and STZ-induced diabetic control rats showed significant $(p<0.05)$ decrease in the level of total $\mathrm{Hb}$ and significant $(p<0.05)$ increase in the levels of HbAlc when compared with normal control rats. The levels of total $\mathrm{Hb}$ were significantly $(p<0.05)$ increased and significantly $(p<0.05)$ decreased in the levels of HbA1c by the treatment with naringin in diabetic rats when compared to HFD and STZ-induced diabetic control rats (Figure 3).

Effect of naringin on the activities of carbohydrate metabolic key enzymes

The activities of glycolytic enzymes (glucokinase) and lipogenic enzyme (glucose-6-phosphate dehydrogenase) were significantly $(p<0.05)$ decreased whereas gluconeogenic enzymes (glucose-6-phosphatase and fructose 1,6 bisphosphate) were significantly $(p<0.05)$ increased in the liver of

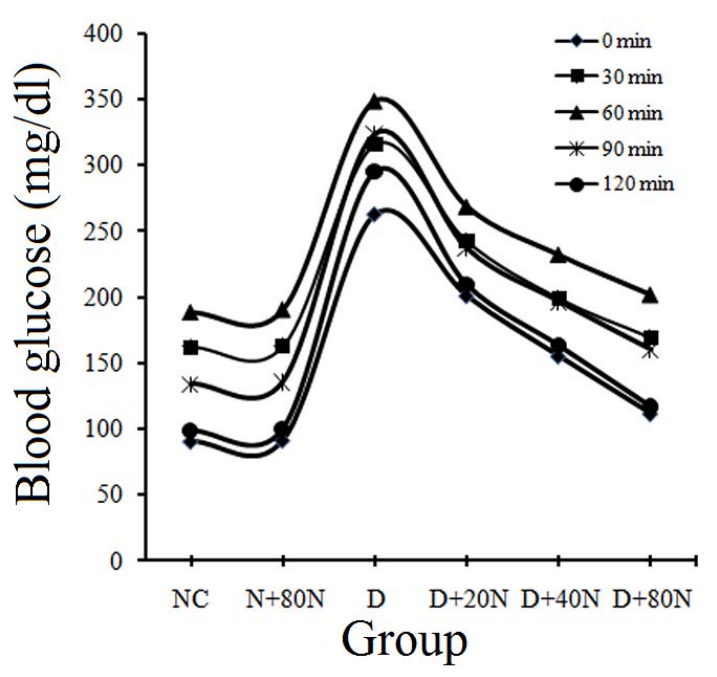

Figure 2. Effect of naringin on glucose level using oral glucose tolerance test (OGTT). Each value is mean \pm SD for six rats in each group. For more abbreviations, see Fig. 1.
HFD and STZ-induced diabetic control rats when compared to normal control rats. Oral treatment with naringin to diabetic rats significantly $(p<0.05)$ increased the activities of glycolytic and lipogenic enzyme whereas significantly $(p<0.05)$ decreased the activities of gluconeogenic enzymes in the liver of diabetic rats when compared to HFD and STZinduced diabetic control rats (Figure 4).

Effects of naringin on glycogen content and glycogen metabolic enzymes

There was a significant $(p<0.05)$ reduction in the hepatic glycogen content and the glycogen synthase activity with concomitant increase in the glycogen phosphorylase activity in HFD and STZ-induced diabetic control rats compared to normal control rats. Oral treatment with naringin to diabetic rats significantly $(p<0.05)$ reversed the content of glycogen and the activities of these glycogen metabolic enzymes when compared to HFD and STZ-induced diabetic control rats (Figure 5).

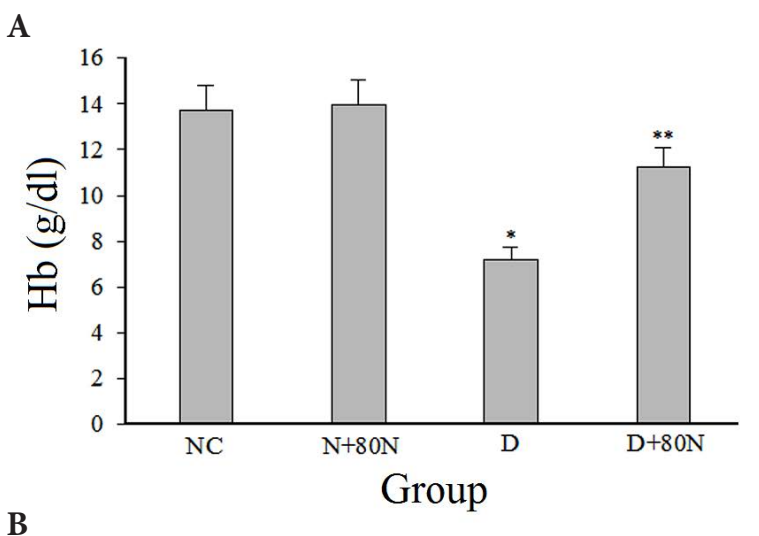

B

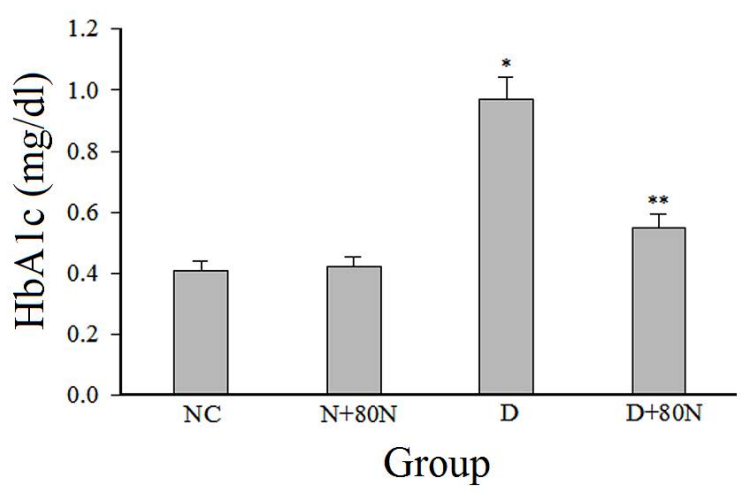

Figure 3. Effect of naringin on the levels of blood $\mathrm{Hb}(\mathbf{A})$ and $\mathrm{HbA1C}(\mathbf{B})$. Each column is mean \pm S.D. for six rats in each group; ${ }^{*} p<0.05$ as compared to normal control. ${ }^{* *} p<0.05$ as compared to HFD+STZ-induced diabetic control. Hb, total haemoglobin; HbAlc, glycosylated haemoglobin. For more abbreviations, see Fig. 1. 
Effect of naringin on immunohistochemical staining of insulin in pancreas

Immunohistochemical observations of pancreas of normal control and experimental rats are shown in Figure 6. Normal control rats showed strong immunoreactivity of insulin in $\beta$-cells, which occupy most of the islets (Fig. 6A), naringin ( $80 \mathrm{mg} / \mathrm{kg}$ b.w.) administered normal rats also showed islets with a relatively large area of insulin-immunoreactivity (Fig. 6B), HFD and STZ-induced diabetic control rats revealed reduced number and area of insulin-immunoreactive $\beta$-cells (Fig. 6C), $80 \mathrm{mg} / \mathrm{kg}$ b.w. naringin-treated diabetic rats revealed moderate increase in the number and area of insulin-immunoreactive $\beta$-cells (Fig. 6D).

\section{Discussion}

HFD will cause insulin resistance in peripheral tissues due to lipotoxicity; meanwhile, low dose of STZ will induce mild defect in insulin secretion (Unger et al. 2010). Combination of HFD with low dose of STZ has therefore successfully mimicked natural progress of DM development as well as metabolic features in human T2DM (Sahin et al. 2007; Franconi et al. 2008). In the present study, HFD and STZ-induced diabetic rats revealed significant reduction in plasma glucose levels on treatment with naringin, which could be due to glucose lowering action through stimulation of remnant $\beta$-cells of Langerhans islets to release more insulin from the pancreas, which confirms the increased levels of plasma insulin in diabetic rats treated with naringin. Our results are in harmony with Mahmoud et al. (2012), who reported that naringin exhibits antihyperglycemic effect in experimental diabetic rats.

The OGTT is playing an important role in the diagnosis of DM as well as screening for abnormal glucose levels (i.e. prediabetes or diabetes). In the present study, the HFD and STZ-induced diabetic rats showed a significant increase in the blood glucose level at $60 \mathrm{~min}$ and was maintained for 120 min following glucose administration in OGTT. In contrast, in naringin-treated diabetic rats the blood glucose

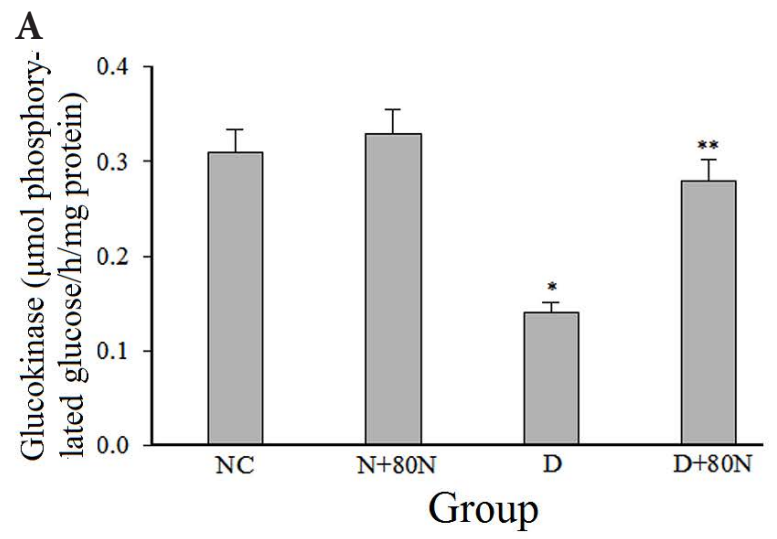

B

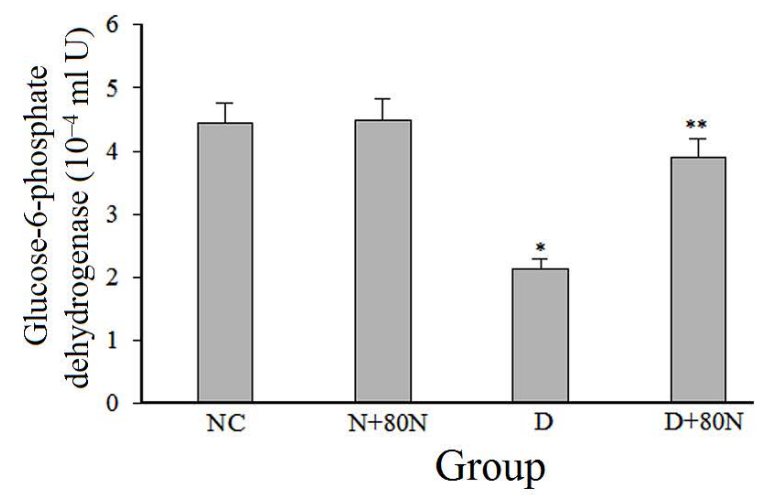

C

D
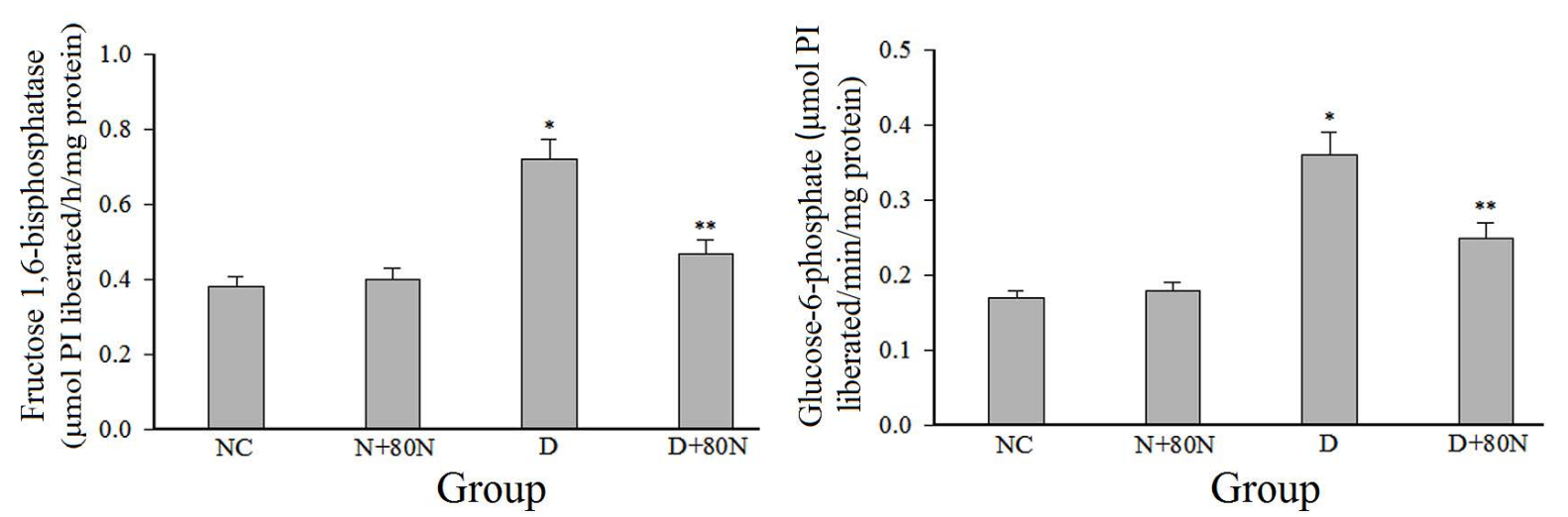

Figure 4. Effect of naringin on changes in the activities of liver glucokinase (A), glucose-6-phosphate dehydrogenase (B), fructose 1,6-bisphosphatase (C) and glucose-6-phosphatase (D) . Each column is mean \pm S.D. for six rats in each group. ${ }^{*} p<0.05$ as compared to normal control; ${ }^{* *} p<0.05$ as compared to HFD+STZ-induced diabetic control. For more abbreviations, see Fig. 1. PI, inorganic phosphate. 
A

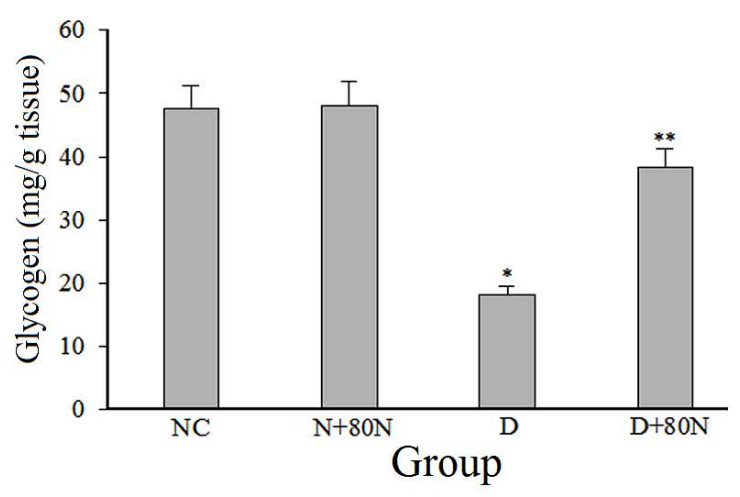

C

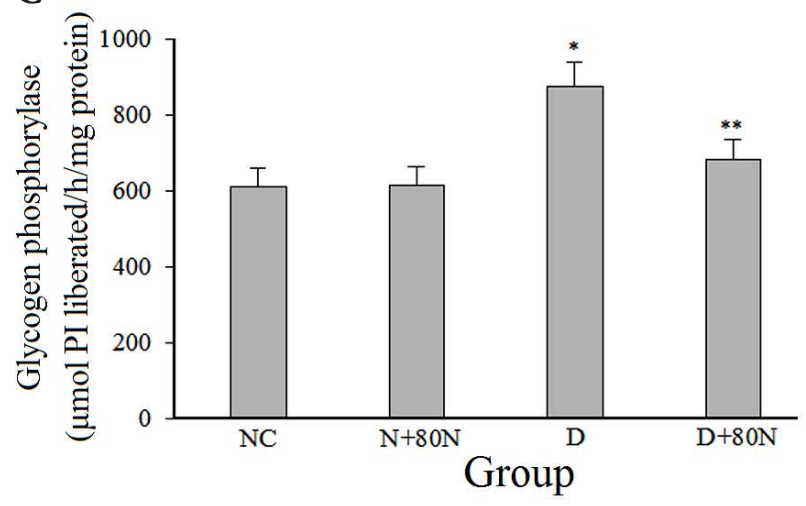

B

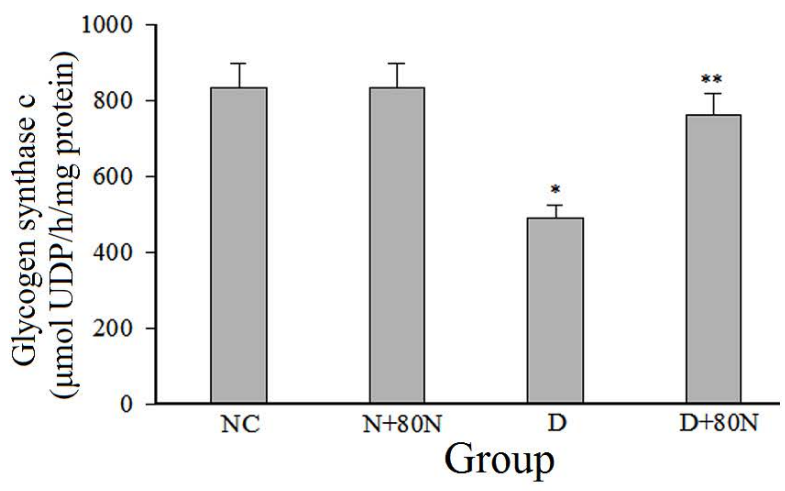

Figure 5. Effect of naringin on glycogen content (A), glycogen synthase (B) and glycogen phosphorylase (C). Each column is mean \pm S.D. for six rats in each group. ${ }^{\star} p<0.05$ as compared to normal control; ${ }^{* *} p<0.05$ as compared to HFD + STZ-induced diabetic control. For more abbreviations, see Fig. 1. reached the fasting levels after $120 \mathrm{~min}$, which showed improvement in the glucose utilization ability of diabetic rats treated with naringin. Similar observations were reported by Sharma et al. (2011).

$\mathrm{HbA} 1 \mathrm{c}$ is a standard biochemical marker as well as a reliable index to monitor glucose lowering therapy and long-term blood sugar control (Kasetti et al. 2010). Decreased levels of total $\mathrm{Hb}$ was noticed in HFD and STZ-induced diabetic rats might be due to the increased formation of HbAlc, which caused by hyperglycemia through non-enzymatic glycosylation (Sundaram et al. 2013). Oral treatment with naringin to HFD and STZ-induced diabetic rats revealed decreased the elevation of $\mathrm{HbAlc}$, thereby increasing the level of total $\mathrm{Hb}$, by virtue of its antihyperglycemic effect.

Glucokinase is the rate-limiting enzyme in the catabolism of glucose, which phosphorylates glucose to glucose-6-phophate and is almost completely inhibited or inactivated in experimental DM (Tiedge et al. 2000), which could be due to decreased utilization of glucose for energy production (Vats et al. 2003). Oral treatment with naringin to HFD and STZ-induced diabetic rats revealed in significant increase in the activity of hepatic glucokinase, which may be due to increase in glycolysis and utilization of glucose for energy production, by virtue of its antihyperglycemic effect. Our results were similar to the report of Jung et al. (2004), who demonstrated that naringin improved glucokinase activity in C57BL/KsJ-db/db Mice.

Glucose-6-phosphate dehydrogenase is the key regulatory enzyme in the pentose phosphate pathway, which results in the production of ribose-5-phosphate and NADPH (Cappai et al. 2011). The hepatic glucose-6-phosphate dehydrogenase activity was found to be decreased in diabetic conditions, suggest a decrease in glucose metabolism via phosphogluconate oxidation pathway (Prasath and Subramanian 2011). Naringin-treated HFD and STZ diabetic rats enhanced the glucose utilization by increasing the activity of glucose6-phosphate dehydrogenase through the pentose phosphate pathway, by virtue of its antihyperglycemic effect.

Gluconeogenesis is a main cause of the elevated hepatic glucose production, contributing $50-60 \%$ of the released glucose (Srinivasan et al. 2014). Excessive hepatic glucose production via the gluconeogenesis pathway is partially responsible for the elevated glucose levels observed in DM (He et al. 2009). Glucose-6-phosphatase and fructose-1,6bisphosphatase are the important enzymes in regulating of gluconeogenic pathway. In the present study, the activities of the hepatic gluconeogenic enzymes were significantly increased in HFD and STZ-induced diabetic rats. The increased activities of these hepatic gluconeogenic enzymes may be due to the activation or increased synthesis of the 

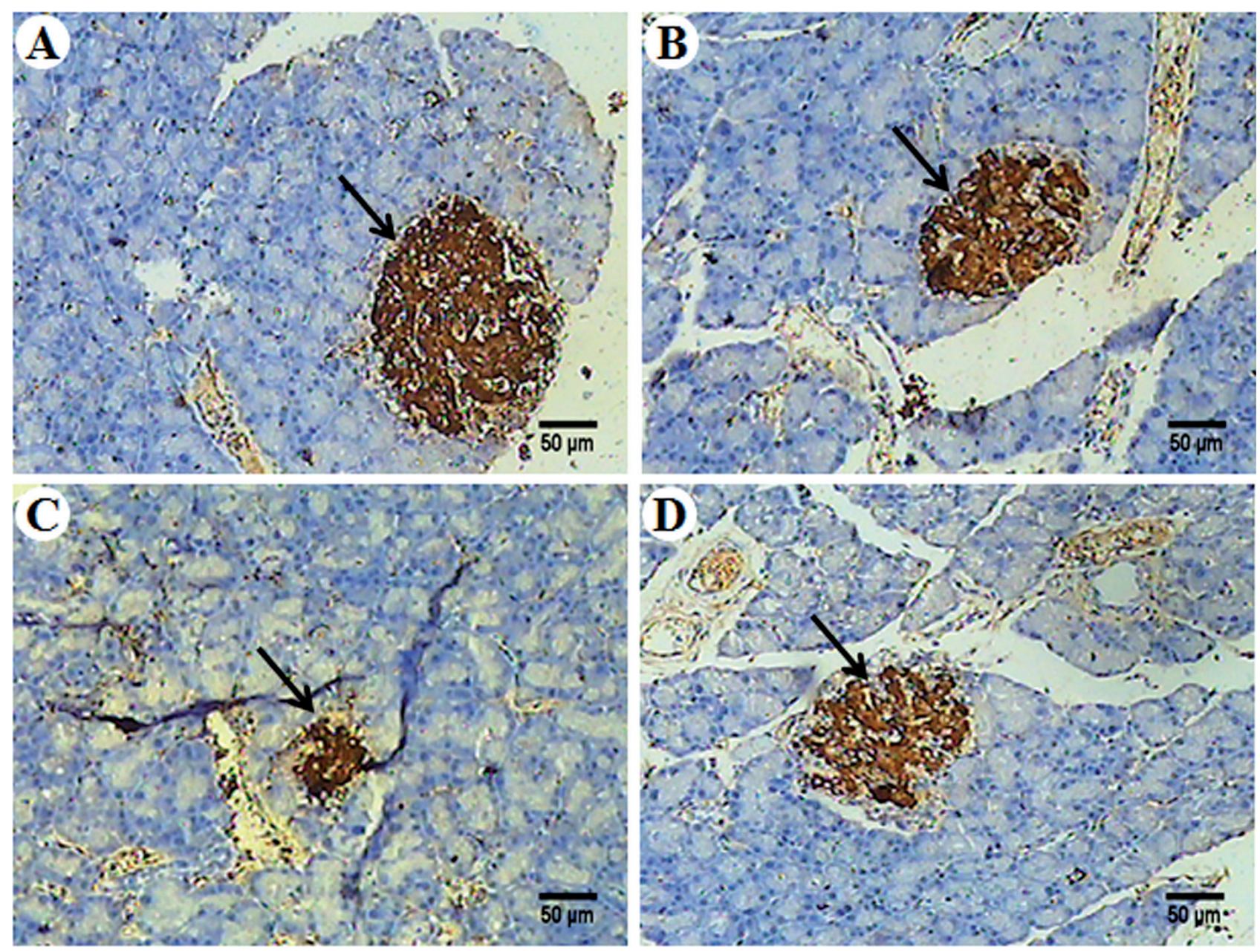

Figure 6. Immunohistochemical observations on the pancreatic tissues in normal control rats (A), normal rats treated with naringin (80 $\mathrm{mg} / \mathrm{kg})(\mathbf{B}), \mathrm{HFD}+\mathrm{STZ}$-induced diabetic control rats (C), diabetic rats treated with naringin $(80 \mathrm{mg} / \mathrm{kg})(\mathbf{D})$. Pancreatic tissue sections stained with anti-insulin antibody were showed at $100 \times$ magnification. The arrow indicates the insulin-immunoreactivity of the section.

enzymes involving to the increased glucose production during DM by liver and naringin treatment may inhibit gluconeogenesis by reduction in the activities of glucose6-phosphatase and fructose-1,6-bisphosphatase, thereby reducing the endogenous production of glucose. These results are agreement in with Jung et al. (2004) who reported that naringin, improves glucose metabolism in type 2 diabetic mice by the inhibition of gluconeogenesis.

Glucose is stored in the form of glycogen in the liver and skeletal muscle, which indicates direct reflection of insulin activity since it regulates glycogen deposition by stimulating glycogen synthase and inhibiting glycogen phosphorylase (Verma et al. 2013). Liver glycogen content that was significantly reduced in HFD and STZ-induced diabetic rats has been attributed to reduced activity of glycogen synthase and increased activity of glycogen phosphorylase. Oral treatment of naringin to stimulating produces more insulin from remnant $\beta$-cells and increase glycogen content in the liver of diabetic rats by increasing the activity of glycogen synthase and inhibiting the activity of glycogen phosphorylase. Our results are also in agreement with the results published in a previous study; the lowering of blood glucose levels was accompanied by increased liver glycogen content after naringin supplementation on glucose metabolism in db/db mice (Jung et al. 2004).

Immunohistochemical staining of pancreas in HFD and STZ-induced diabetic rats showed that reduced number and area of insulin-immunoreactive $\beta$-cells. Naringin treatment to diabetic rats revealed well-defined islets and strong insulinimmunoreactive staining were observed, which suggested that naringin stimulate increase insulin secretion from remnant pancreatic $\beta$-cells and maintains blood glucose levels in diabetic rats, by virtue of its antihyperglycemic effect.

Numerous studies have revealed that hyperglycemia causes the deterioration of pancreatic $\beta$-cells due to oxidative 
stress (Kaneto et al. 1999, 2001). Hence, antioxidants can have beneficial effects on pancreatic $\beta$-cells by neutralizing the oxidative stress. Previous study revealed that, naringin treatment significantly prevents lipid peroxidation and improves antioxidant status in HFD and STZ-induced type 2 diabetic rats. Thus, naringin scavenges excessive free radicals produced by STZ and reduces oxidative stress, by virtue of its antioxidant effect (Mahmoud et al. 2012).

In conclusion, from the above findings revealed that naringin appears to possess antihyperglycemic activity via modulating plasma glucose and insulin levels as well as the enzymes involved in the glucose and glycogen metabolism and its protective effects on hepatic tissue in HFD and STZinduced diabetic rats.

Acknowledgement. We thank the University Grants Commission (UGC), New Delhi, India for the research grant support (Project No. 41-1255/2012 (SR)).

\section{References}

American Diabetes Association (2011): Diagnosis and classification of diabetes mellitus. Diabetes Care 34, 62-69 https://doi.org/10.2337/dc11-S062

Brandstrup N., Kirk J. E., Bruni C. (1957): Determination of glucokinase in tissues. J. Gerontol. 12, 166-171 https://doi.org/10.1093/geronj/12.2.166

Cappai G., Songini M., Doria A., Cavallerano J. D., Lorenzi M. (2011): Increased prevalence of proliferative retinopathy in patients with type 1 diabetes who are deficient in glucose6-phosphate dehydrogenase. Diabetologia 54, 1539-1542 https://doi.org/10.1007/s00125-011-2099-3

Chandramohan R., Pari L., Rathinam A., Sheikh B. A. (2015): Tyrosol, a phenolic compound, ameliorates hyperglycemia by regulating key enzymes of carbohydrate metabolism in streptozotocin induced diabetic rats. Chem. Biol. Interact. 229, 44-54 https://doi.org/10.1016/j.cbi.2015.01.026

Chanet A., Milenkovic D., Deval C., Potier M., Constans J., Mazur A. (2012): Naringin, the major grapefruitflavonoid, specifically affects atherosclerosis development in diet-induced hypercholesterolemia in mice. J. Nutr. Biochem. 23, 469-477 https://doi.org/10.1016/j.jnutbio.2011.02.001

Du Vigneaud V., Karr W. G. (1925): Carbohydrates utilization rate of disappearance of D-glucose from the blood. J. Biol. Chem. 66, 281-300

Ells H. A., Kirkman H. N. (1961): A colorimetric method for assay of erythrocytic glucose-6-phosphate dehydrogenase. Proc. Soc. Exp. Biol. Med. 106, 607-609 https://doi.org/10.3181/00379727-106-26418

Fiske C. H., Subbarow J. (1925): The colorimetric determination of phosphorous. J. Biol. Chem. 66, 375-400

Franconi F., Seghieri G., Canu S., Straface E., Campesi I., Malorni W. (2008): Are the available experimental models of type 2 diabetes appropriate for a gender perspective? Pharmacol. Res. 57, 6-18 https://doi.org/10.1016/j.phrs.2007.11.007

Gancedo J. M., Gancedo C. (1971): Fructose-1,6-diphosphatase, phosphofructokinase and glucose-6-phosphate dehydrogenase from fermenting and non fermenting yeasts. Arch. Mikrobiol. 76, $132-138$ https://doi.org/10.1007/BF00411787

Golden S., Wals P. A., Katz J. (1977): An improved procedure for the assay of glycogen synthase and phosphorylase in rat liver homogenates. Anal. Biochem. 77, 436-445 https://doi.org/10.1016/0003-2697(77)90257-3

Golechha M., Chaudhry U., Bhatia J., Saluja D., Arya D. S. (2011): Naringin protects against kainic acid-induced status epilepticus in rats: evidence for an antioxidant, anti-inflammatory and neuroprotective intervention. Biol. Pharm. Bull. 34, 360-365 https://doi.org/10.1248/bpb.34.360

He L., Sabet A., Djedjos S., Miller R., Sun X., Hussain M. A., Radovick S., Wondisford F. E. (2009): Metformin and insulin suppress hepatic gluconeogenesis through phosphorylation of CREB binding protein. Cell 137, 635-646 https://doi.org/10.1016/j.cell.2009.03.016

Jeon S. M., Bok S. H., Jang M. K., Lee M. K., Nam K. T., Park Y. B., Rhee S. J., Choi M. S. (2001): Antioxidative activity of naringin and lovastatin in high cholesterol-fed rabbits. Life Sci. 69, 2855-2866 https://doi.org/10.1016/S0024-3205(01)01363-7

Jian L. J. Q., Joyce T., Christina K. H., Cynthia S., Richard H., Gerald M. R. (1998): Nongenetic mouse models of non-insulin dependent diabetes mellitus. Metabolism 47, 663-668 https://doi.org/10.1016/S0026-0495(98)90027-0

Jung U. J., Lee M. K., Jeong K. S., Choi M. S. (2004): The hypoglycemic effects of hesperidin and naringin are partly mediated by hepatic glucose-regulating enzymes in C57BL/KsJ-db/db mice. J. Nutr. 134, 2499-2503

Kaneto H., Kajimoto Y., Fujitani Y., Matsuoka T., Sakamoto K., Matsuhisa M., Yamasaki Y., Hori M. (1999): Oxidative stress induces p21 expression in pancreatic islet cells: possible implication in beta-cell dysfunction. Diabetologia 42, 1093-1097 https://doi.org/10.1007/s001250051276

Kaneto H., Xu G., Song K. H., Suxuma K., Bonner-Weir S., Sharma A., Weir, G. C. (2001): Activation of the hexosamine pathway leads to deterioration of pancreatic $\beta$-cell function through the induction of oxidative stress. J. Biol. Chem. 276, 31099-31104 https://doi.org/10.1074/jbc.m104115200

Kasetti R. B., Rajasekhar M. D., Kondeti V. K., Fatima S. S., Kumar E. G., Swapna S. (2010): Antihyperglycemic and antihyperlipidemic activities of methanol: water (4:1) fraction isolated from aqueous extract of Syzygium alternifolium seeds in streptozotocin induced diabetic rats. Food Chem. Toxicol. 48, 1078-1084 https://doi.org/10.1016/j.fct.2010.01.029

Koide H., Oda T. (1959): Pathological occurrence of glucose6-phosphatase in serum in liver diseases. Clin. Chim. Acta $4,554-561$ https://doi.org/10.1016/0009-8981(59)90165-2

Liu Z., Li W., Li X., Zhang M., Chen L., Zheng Y., Sun G., Ruan C. (2013): Antidiabetic effects of malonyl ginsenosides from Panax ginsengon type 2 diabetic rats induced by high-fat diet and streptozotocin. J. Ethnopharmacol. 145, 233-240 https://doi.org/10.1016/j.jep.2012.10.058 
Lowry O. H., Rosebrough N. J., Farr A. L., Randall R. J. (1951): Protein measurement with the Folin phenol reagent, J. Biol. Chem. 193, 265-275

Mahmoud A. M., Ashour M. B., Abdel-Moneim A., Ahmed O. M. (2012): Hesperidin and naringin attenuate hyperglycemiamediated oxidative stress and proinflammatory cytokine production in high fat fed/streptozotocin-induced type 2 diabetic rats. J. Diabetes Complicat. 26, 483-490 https://doi.org/10.1016/j.jdiacomp.2012.06.001

McAnuff M. A., Omoruyi F. O., Morrison E. Y., Asemota H. N. (2005): Changes in some liver enzymes in streptozotocininduced diabetic rats fed sapogenin extract from bitter yam (Dioscorea polygonoides) or commercial diosgenin. West Indian Med. J. 54, 97-101 https://doi.org/10.1590/s0043-31442005000200002

Mirmiran P., Bahadoran Z., Azizi F. (2014): Functional foods-based diet as a novel dietary approach for management of type 2 diabetes and its complications: a review. World J. Diabetes 5, 267-281 https://doi.org/10.4239/wjd.v5.i3.267

Morales M. A., Jabbagy A. J., Terenizi H. R. (1973): Mutations affecting accumulation of glycogen. Neurospora Newsletter 20, 24-25 https://doi.org/10.4148/1941-4765.1830

Prabhakar P. K., Prasad R., Ali S., Doble M. (2013): Synergistic interaction of ferulic acid with commercial hypoglycemic drugs in streptozotocin induced diabetic rats. Phytomedicine 20, $488-494$ https://doi.org/10.1016/j.phymed.2012.12.004

Prasath G. S., Subramanian S.P. (2011): Modulatory effects of fisetin, a bioflavonoid, on hyperglycemia by attenuating the key enzymes of carbohydrate metabolism in hepatic and renal tissues in streptozotocin-induced diabetic rats. Eur. J. Pharmacol. 668, 492-496 https://doi.org/10.1016/j.ejphar.2011.07.021

Sahin, K., Onderci M., Tuzcu M. (2007): Effect of chromium on carbohydrate and lipid metabolism in a rat model of type 2 diabetes mellitus: the fat-fed, streptozotocin-treated rat. Metab. Clin. Exp. 56, 1233-1240 https://doi.org/10.1016/j.metabol.2007.04.021

Salas-Salvado J., Martinez-Gonza 'lez M. A., Bullo M., Ros E. (2011): The role of diet in the prevention of type 2 diabetes. Nutr. Metab. Cardiovasc. Dis. 21, 32-48 https://doi.org/10.1016/j.numecd.2011.03.009

Sharma A. K., Bharti S., Ojha S., Bhatia J., Kumar N., Ray R., Kumari S., Arya D. S. (2011): Up-regulation of PPAR $\gamma$, heat shock protein- 27 and -72 by naringin attenuates insulin resistance, $\beta$-cell dysfunction, hepatic steatosis and kidney damage in a rat model of type 2 diabetes. Br. J. Nutr. 106, 1713-1723 https://doi.org/10.1017/S000711451100225X
Shull K. H., Ashmore J., Mayer J. (1956): Hexokinase, glucose6-phosphatase and phosphorylase levels in hereditarily obese-hyperglycemic mice. Arch. Biochem. Biophys. 62, $210-216$ https://doi.org/10.1016/0003-9861(56)90104-7

Skovsø S. (2014): Modeling type 2 diabetes in rats using high fat diet and streptozotocin. J. Diabetes Investig. 5, 349-358 https://doi.org/10.1111/jdi.12235

Srinivasan S., Sathish G., Jayanthi M., Muthukumaran J., Muruganathan U., Ramachandran V. (2014): Ameliorating effect of eugenol on hyperglycemia by attenuating the key enzymes of glucose metabolism in streptozotocin-induced diabetic rats. Mol. Cell. Biochem. 385, 159-168 https://doi.org/10.1007/s11010-013-1824-2

Sundaram R., Naresha R., Shanthi P., Sachdanandam P. (2013): Modulatory effect of green tea extract on hepatic key enzymes of glucose metabolism in streptozotocin and high fat diet induced diabetic rats. Phytomedicine 20, 577-584 https://doi.org/10.1016/j.phymed.2013.01.006

Tapas A. R., Sakarkar D. M., Kakde R. B. (2008): Flavonoids as nutraceuticals: A review. Trop. J. Pharm. Res. 7, 1089-1099 https://doi.org/10.4314/tjpr.v7i3.14693

Tiedge M., Richter T., Lenzen S. (2000): Importance of cysteine residues for the stability and catalytic activity of human pancreatic beta cell glucokinase. Arch. Biochem. Biophys. 375, 251-260 https://doi.org/10.1006/abbi.1999.1666

Trinder P. (1969): Determination of glucose in blood using glucose oxidase with an alternative oxygen acceptor. Ann. Clin. Biochem. 6, 24-27 https://doi.org/10.1177/000456326900600108

Unger R. H., Clark G. O., Scherer P. E., Orci L. (2010): Lipid homeostasis, lipotoxicity and the metabolic syndrome. Biochim. Biophys. Acta 1801, 209-214 https://doi.org/10.1016/j.bbalip.2009.10.006

Vats V., Yadav S. P., Grover J. K. (2003): Effect of Trigonella foenum graecumon glycogen content of tissues and the key enzymes of carbohydrate metabolism. J. Ethnopharmacol. 85, 237-242 https://doi.org/10.1016/S0378-8741(03)00022-9

Verma N., Amresh G., Sahu P. K., Mishra N., Ch Rao V., Singh A. P. (2013): Pharmacological evaluation of hyperin for antihyperglycemic activity and effect on lipid profile in diabetic rats. Indian J. Exp. Biol. 51, 65-72

Zbarsky V., Datla K. P., Parkar S., Rai D. K., Aruoma O. I., Dexter D. T. (2005): Neuroprotective properties of the natural phenolic antioxidants curcumin and naringenin but not quercetin and fisetin in a 6-OHDA model of Parkinson's disease. Free Radic. Res. 39, 1119-1125 https://doi.org/10.1080/10715760500233113

Received: July 22, 2016

Final version accepted: November 20, 2016 